\title{
Electrophysiological properties of intravenous metoprolol in man
}

\author{
PAOLO RIZZON, MATTEO DI BIASE, ADELE CHIDDO, \\ DOMENICO MASTRANGELO, AND LUIGI SORGENTE
}

From the Department of Cardiology, University of Bari, Bari, Italy

SUMMARY Electrophysiological changes produced by intravenous $(0 \cdot 1 \mathrm{mg} / \mathrm{kg})$ metoprolol, a new selective $\beta_{1}$-blocking agent devoid of intrinsic activity, were studied in 16 subjects with estimated normal impulse formation and conduction.

The most important effects were sinus bradycardia, mild increase of sinoatrial conduction time, depression of intranodal conduction, and prolongation of AV node refractory periods. Sinus node recovery time and atrial refractory periods were unmodified. Infranodal conduction and the refractory periods of the His-Purkinje system, as well as of the bundle-branches, were unchanged.

These effects are compared with those observed after intravenous propranolol, pindolol, and oxprenolol.

During the past 10 years a number of adrenergic $\beta$-receptor antagonists, e.g. propranolol, alprenolol, pindolol, oxprenolol, and practolol, have been widely used in the treatment of angina, hypertension, and arrhythmias. Of these drugs, only practolol proved to be a selective inhibitor of $\beta_{1}$ receptors. Recently, another $\beta_{1}$-selective blocker, metoprolol $^{1}$, has been described. Unlike practolol, this compound is devoid of $\beta$-receptor stimulating properties, that is 'intrinsic activity' (Ablad et al., 1973, 1975). Metoprolol is equipotent to propranolol as regards blockade of the cardiac response to sympathetic nerve stimulation, of cardiac lipolytic and renin release responses to noradrenaline (Ablad et al., 1975), and is almost equipotent as regards inhibition of the tachycardic response to exercise (Johnsson, 1975). Metoprolol has been shown to be relatively devoid of propranolol's local anaesthetic effect which can produce cardiodepression (Ablad et al., 1973). No studies have been made to test the electrophysiological properties of this drug.

The present work was undertaken to determine the electrophysiological effects of intravenously administered metoprolol in 16 human subjects with estimated normal impulse formation and conduction.

${ }^{1}$ Metoprolol is also known as $\mathrm{H} \mathrm{93/26} \mathrm{(AB} \mathrm{Hassle,} \mathrm{Sweden)} \mathrm{and}$ CGP 2175 (Ciba-Geigy AG, Switzerland).

Received for publication 9 May 1977

\section{Subjects and methods}

Studies were carried out on 16 subjects who underwent a His bundle electrogram study because of a history of cardiac arrhythmia. Informed consent was obtained from all subjects. Clinical data are presented in Table 1 . All subjects were in sinus rhythm and had QRS duration of less than $0.12 \mathrm{~s}$ and normal conduction intervals as measured by His bundle recording technique (Scherlag et al., 1969). Cardiac drugs were withheld for at least 72 hours before beginning the study.

Table 1 Clinical data of 16 cases who entered study

\begin{tabular}{rllll}
\hline Patients & $\begin{array}{c}\text { Age } \\
(y)\end{array}$ & Sex & $\begin{array}{l}\text { Cardiac } \\
\text { diagnosis }\end{array}$ & $\begin{array}{l}\text { Indication for } \\
\text { electrophysiological study }\end{array}$ \\
\hline 1 & 58 & M & ASHD & Atrial extrasystoles \\
2 & 69 & M & ASHD & Atrial extrasystoles \\
3 & 47 & F & NHD & Paroxysmal atrial fibrillation \\
4 & 63 & M & ASHD & Ventricular extrasystoles \\
5 & 37 & M & NHD & Atrial extrasystoles \\
6 & 41 & M & ASHD & Ventricular extrasystoles \\
7 & 47 & M & ASHD & Paroxysmal atrial fibrillation \\
8 & 58 & M & ASHD & Ventricular extrasystoles \\
9 & 48 & M & ASHD & Ventricular extrasystoles \\
10 & 33 & M & NHD & Paroxysmal atrial fibrillation \\
11 & 48 & M & ASHD & Ventricular extrasystoles \\
12 & 54 & M & ASHD & Atrial extrasystoles \\
13 & 47 & M & ASHD & Paroxysmal atrial flutter \\
14 & 45 & M & ASHD & Paroxysmal atrial tachycardia \\
15 & 55 & M & NHD & Paroxysmal atrial tachycardia \\
16 & 43 & M & ASHD & Paroxysmal atrial fibrillation \\
\hline
\end{tabular}

ASHD, atherosclerotic heart disease; NHD, no heart disease. 
Electrode catheters were introduced percutaneously into the right femoral vein. A $6 \mathrm{~F}$ bipolar catheter was positioned across the tricuspid valve to record His bundle electrograms; a $6 \mathrm{~F}$ quadripolar catheter was positioned against the lateral wall of the right atrium near its junction with the superior vena cava. Proximal electrodes were used to record high atrial electrograms and distal electrodes were connected to a DTU 110 external pulse generator ${ }^{1}$ for pacing. Standard leads I, III, and V1 and intracardiac electrograms were displayed on a multichannel oscilloscope and recorded at $100 \mathrm{~mm} / \mathrm{s}$ paper speed on an 8-channel Hewlett-Packard 4368 $C$ photographic recorder at a frequency setting of 50 to $500 \mathrm{~Hz}$. Basic unstimulated intervals were recorded first.

In 11 patients (group A), controlled drive stimuli $S_{1}$ were delivered to the high right atrium: $S_{1}$ was first adjusted to a rate just fast enough to ensure atrial capture. $S_{2}$ was then introduced in 10 to $20 \mathrm{~ms}$ decrements, after every eighth $S_{1}$, until no intracardiac response occurred. Stimuli pulses were rectangular, $2 \mathrm{~ms}$ in duration, and approximately twice the diastolic threshold. Fast atrial pacing was subsequently performed, increasing the heart rate by 10 beats per minute during each test, until a second degree type I supra-His AV block was produced. $A_{1}, H_{1}$, and $V_{1}$ were atrial $H i s$ bundle, and ventricular electrograms induced by $S_{1}$; $A_{2}, H_{2}$, and $V_{2}$ were corresponding electrograms induced by $\mathrm{S}_{2}$.

In 5 patients (group B), premature atrial stimuli were introduced after every eight sinus beats and moved in $20 \mathrm{~ms}$ increments, using the $R$ wave to trigger the stimulator. In this way, the entire atrial diastolic period was scanned for determination of mean sinoatrial conduction time (SACT). To evaluate sinus node automaticity, atrial pacing at three different heart rates $(120 / \mathrm{min}, 130 / \mathrm{min}$, and $140 / \mathrm{min}$ ) for periods of one minute, was performed. After each atrial pacing, a rest period of $30 \mathrm{~s}$ was given to allow the rhythm to return to its basic level.

All studies were performed before and 2, 15, and 30 minutes, respectively, after $0 \cdot 1 \mathrm{mg} / \mathrm{kg}$ metoprolol had been administered intravenously for 2 minutes.

\section{Definition of terms}

Atrial effective refractory period was the longest $\mathrm{S}_{1}-\mathrm{S}_{2}$ interval at which atrial capture failed to occur. Atrial functional refractory period was the shortest $A_{1}-A_{2}$ attainable. AV nodal effective refractory period was the longest $A_{1}-A_{2}$ interval which did not propagate to the His bundle. AV nodal functional 'Manufactured by M. Bloom, Philadelphia, USA.
Table 2 Effects of metoprolol on sinus cycle lengths, intra-atrial, intranodal, and intraventricular conduction in $\mathrm{man}^{\star}$

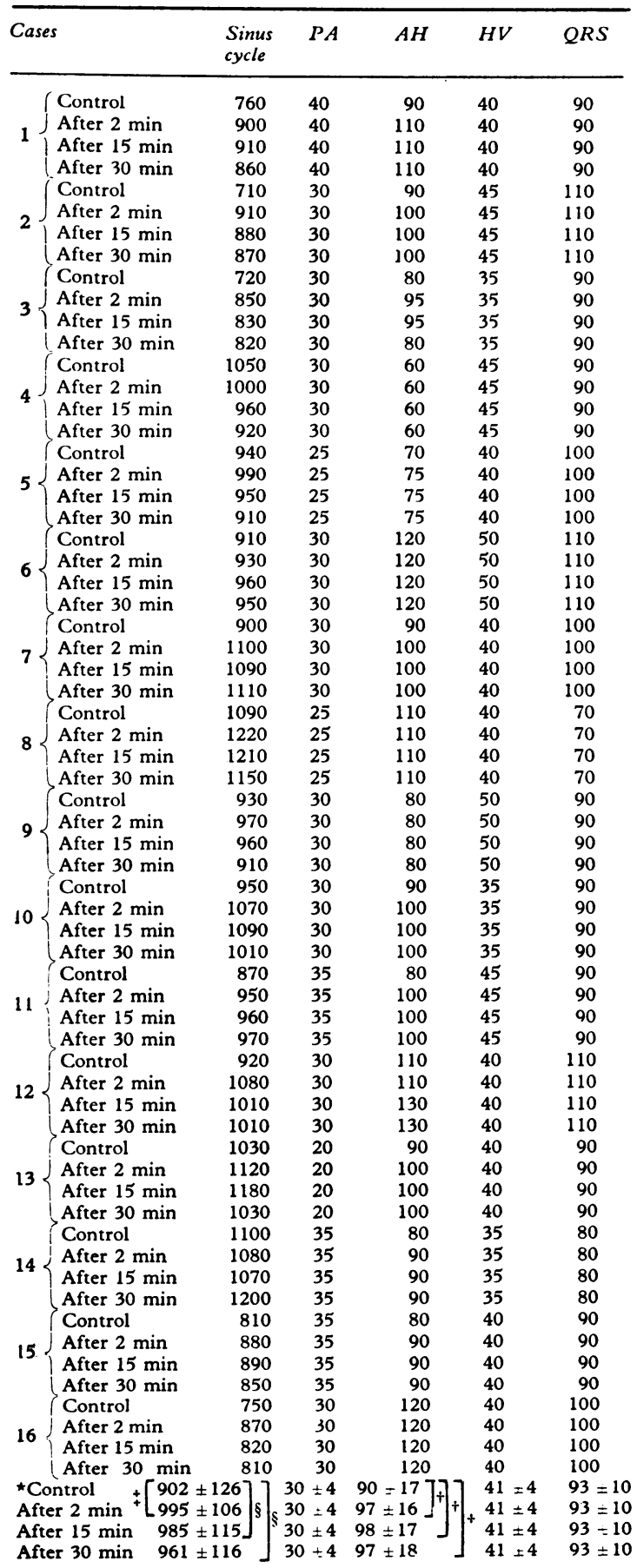

*All values in ms.

Significance of difference from control: $t<0.01 ;+<0.02 ; \S<0.05$ 
refractory period was the shortest propagated $\mathrm{H}_{1}-\mathrm{H}_{2}$ interval. Effective and functional refractory periods of the His-Purkinje system were, respectively, the longest $\mathrm{H}_{1}-\mathrm{H}_{2}$ interval not propagated to the ventricle and the longest $\mathrm{H}_{1}-\mathrm{H}_{2}$ interval followed by an increase in the $\mathrm{H}_{2}-\mathrm{V}_{2}$ interval. The relative refractory period of a bundle-branch was considered the longest $\mathrm{H}_{1}-\mathrm{H}_{2}$ interval producing the electrocardiographic pattern of complete bundle-branch block.

Wenckebach point was the lowest driven atrial rate producing $\mathrm{AV}$ nodal Wenckebach periods.

Mean sinoatrial conduction time (SACT) was calculated from the formula

$$
S A C T=\frac{A_{2}-A_{3}-A_{1}-A_{1}}{2}
$$

(Strauss et al., 1973). Sinus node recovery time was the pause observed after overdrive pacing, and it was defined as the interval from the last paced $P$ wave to the first spontaneously occurring $P$ wave, and expressed as a percentage (pause/control P-P $\times 100$ ) (Mandel et al., 1971).

Results are presented as the mean \pm standard error using Student's $t$ test for paired data. Differences were considered significant when $P$ was less than $0 \cdot 05$.

Table 3 Effects of metoprolol on sinus node automaticity and sinoatrial conduction in man

\begin{tabular}{|c|c|c|c|c|}
\hline Cases & $\begin{array}{l}\text { SNRT } \\
120 / \mathrm{min}\end{array}$ & $130 / \min$ & $140 / \min$ & $\begin{array}{l}S A C T \\
\text { (ms) }\end{array}$ \\
\hline Control & $109 \%$ & $117 \%$ & $96 \%$ & 92 \\
\hline $12 \int$ After $2 \mathrm{~min}$ & $115 \%$ & $113 \%$ & $117 \%$ & 102 \\
\hline 12 After $15 \mathrm{~min}$ & $115 \%$ & $127 \%$ & $127 \%$ & 106 \\
\hline After $30 \mathrm{~min}$ & $115^{\circ}$ & $121^{\circ} \mathrm{o}$ & $129 \%$ & 94 \\
\hline Control & $118 \%$ & $122 \%$ & $122^{\circ}$ & 92 \\
\hline 13 After $2 \mathrm{~min}$ & $123 \%$ & $122 \%$ & $122^{\circ}$ & 135 \\
\hline After $15 \mathrm{~min}$ & $112 \%$ & $113 \%$ & $102 \%$ & 92 \\
\hline After $30 \mathrm{~min}$ & $129 \%$ & $114 \%$ & $105 \%$ & 92 \\
\hline Control & $120 \%$ & $132 \%$ & $119 \%$ & 131 \\
\hline 14. After $2 \mathrm{~min}$ & $133 \%$ & $130 \%$ & $115^{\circ}$ o & 149 \\
\hline $14\{$ After $15 \mathrm{~min}$ & $129 \%$ & $107 \%$ & $108 \%$ & 120 \\
\hline After $30 \mathrm{~min}$ & $131 \%$ & $139^{\circ}$ & $116 \%$ & 113 \\
\hline Control & $118 \%$ & $134 \%$ & $122^{\circ} \mathrm{o}$ & 70 \\
\hline $15\{$ After $2 \mathrm{~min}$ & $125 \%$ & $143 \%$ & $139^{\circ}$ o & 79 \\
\hline $15\left\{\begin{array}{l}\text { After } 15 \mathrm{~min} \\
\text {. }\end{array}\right.$ & $133 \%$ & $150 \%$ & $137^{\circ}$ & 81 \\
\hline After $30 \mathrm{~min}$ & $139 \%$ & $133^{\circ}$ & $135^{\circ}$ & 58 \\
\hline Control & $117 \%$ & $124 \%$ & $133^{\circ} \circ$ & 92 \\
\hline After $2 \mathrm{~min}$ & $140 \%$ & $115^{\circ}$ & $129^{\circ} \%$ & 114 \\
\hline After $15 \mathrm{~min}$ & $148 \%$ & $136 \%$ & $142 \%$ & 117 \\
\hline After $30 \mathrm{~min}$ & $137 \%$ & $154 \%$ & $143 \%$ & 105 \\
\hline \multirow{4}{*}{$\begin{array}{l}\text { Control } \\
\text { After } 2 \mathrm{~min} \\
\text { After } 15 \mathrm{~min} \\
\text { After } 30 \mathrm{~min}\end{array}$} & $125 \pm 9 \%$ & & $95 \pm 227$ & \\
\hline & $124 \pm 10 \%$ & & $115 \pm 27$ & $\S$ \\
\hline & $125 \pm 15 \%$ & & $103 \pm 16\rfloor$ & \\
\hline & $129 \pm 13^{\circ}$ & & $92 \pm 21$ & \\
\hline
\end{tabular}

Abbreviations: SNRT, sinus node recovery time; SACT, sinoatrial conduction time.

Significance of difference from control: $\$ P<0.05$.

\section{Results}

No untoward side effects were observed after intravenous administration of metoprolol. Its effects on sinus cycle length and conduction intervals are listed in Table 2, those on sinus node recovery time and sinoatrial conduction time in Table 3 , and those on refractoriness and Wenckebach point are listed in Table 4.

\section{SINUS NODE FUNCTION}

(a) Sinus cycle length was prolonged in 14 cases $(87 \%)$ increasing from an average value of $902 \pm 126$ $\mathrm{ms}$ to $995 \pm 106 \mathrm{~ms} \quad(\mathrm{P}<0.02), 985 \pm 115 \mathrm{~ms}$ $(\mathrm{P}<0.05)$, and $961 \pm 116 \mathrm{~ms}(\mathrm{P}<0.05)$ after 2,15 , o. and 30 minutes, respectively. (b) Control sinus node recovery time (mean of calculated values for the three rates of atrial pacing) was $125 \pm 9$ per cent. It was $124 \pm 10$ per cent, $125 \pm 15$ per cent, and $129 \pm 13$ per cent 2,15 , and 30 minutes, respectively, after metoprolol (not significant).

\section{SINOATRIAL CONDUCTION}

Sinoatrial conduction time increased (Fig. 1) from the average value of $95 \pm 22 \mathrm{~ms}$ to $115 \pm 27 \mathrm{~ms}$ $(P<0.05), 103 \pm 16 \mathrm{~ms}(P<0.05)$, and $92 \pm 21 \mathrm{~ms}$ (not significant) after 2, 15, and 30 minutes, respectively.

\section{INTRA-ATRIAL CONDUCTION AND}

ATRIUM REFRACTORY PERIODS

Intra-atrial conduction time (PA interval) was not modified by metoprolol. Mean values of atrium effective refractory period varied from $240 \pm 33 \mathrm{~ms}$ to $242 \pm 33 \mathrm{~ms}, 245 \pm 39 \mathrm{~ms}$, and $241 \pm 35 \mathrm{~ms}$, respectively, after 2,15 , and 30 minutes (not significant). Atrial functional refractory period varied from $289 \pm 31 \mathrm{~ms}$ to $298 \pm 33 \mathrm{~ms}, 296 \pm 29 \mathrm{~ms}$, and $298 \pm 29 \mathrm{~ms}$, respectively, after 2,15 , and $30 \mathrm{~min}-$ utes (not significant).

\section{INTRANODAL CUNDUCTION AND}

\section{NODAL REFRACTORY PERIODS}

AH interval was prolonged in 11 cases $(68 \%)$. The increase was in the range of 5 to $20 \mathrm{~ms}$; average values varied from $90 \pm 17 \mathrm{~ms}$ to $97 \pm 16 \mathrm{~ms} \omega$ $(P<0.01), 98 \pm 17 \mathrm{~ms} \quad(P<0.01)$, and $97 \pm 18 \mathrm{~ms}$ ? $(P<0.01)$ after 2,15 , and 30 minutes, respectively. AV node effective refractory period (Fig. 2), measured $\mathbb{\Phi}$ in the control study in 3 cases, was increased by 10 to $60 \mathrm{~ms}$. In another 2 cases, it was determined only after metoprolol and it was 40 to $80 \mathrm{~ms}$ longer than $\overrightarrow{\mathrm{D}}$ the atrial effective refractory period. Functional $\frac{\rho}{\mathbb{D}}$ refractory period of the $\mathrm{AV}$ node increased in $9 \cong$ cases $(81 \%)$, the increase ranging between 10 and $90 \mathrm{~ms}$. Mean values increased from $446 \pm 43 \mathrm{~ms}$ to

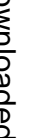

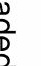


Table 4 Effects of metoprolol on refractoriness and Wenckebach point in man *

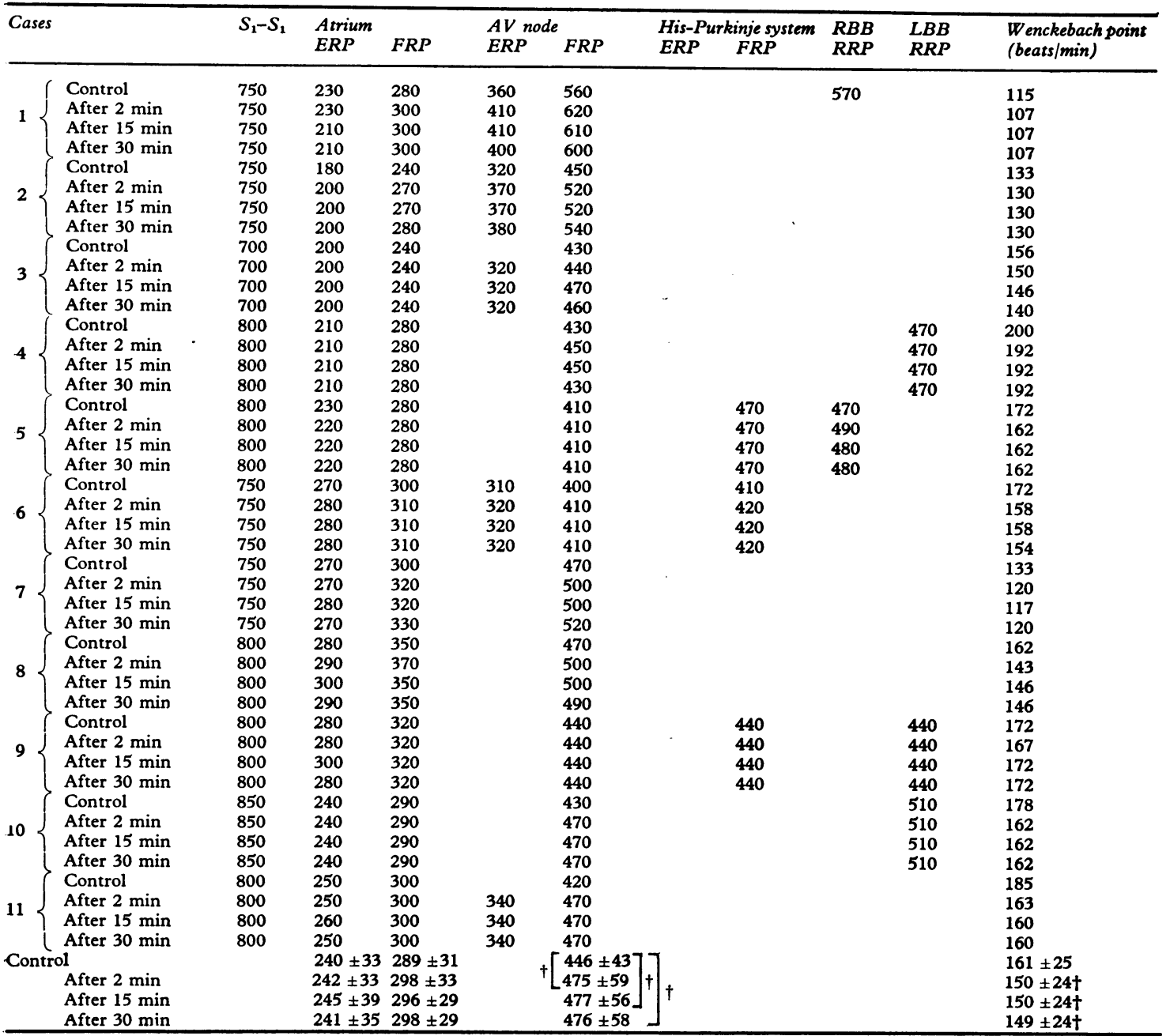

*All values in $\mathrm{ms}$.

Abbreviations: ERP, effective refractory period; FRP, functional refractory period; $R R P$, relative refractory period; $R B B$, right bundle-branch; LBB, left bundle-branch.

Significance of difference from control: $+P<0.01$.

$475 \pm 59 \mathrm{~ms}, 477 \pm 56 \mathrm{~ms}$, and $476 \pm 58 \mathrm{~ms}$ after 2 , 15 , and 30 minutes, respectively $(P<0.01)$.

Wenckebach point was lowered in all cases (Fig. 3). Mean values varied from $161 \pm 25$ beats/min to $150 \pm 24,150 \pm 24$, and $149 \pm 24$ beats/min after 2 , 15 , and 30 minutes, respectively $(P<0.01)$.

\section{INFRANODAL CONDUCTION}

No modifications were observed with regard to $\mathrm{HV}$ interval, functional refractory period of the HisPurkinje system measured in 2 cases, relative refractory period of the right bundle-branch measured in 2 cases, relative refractory period of the left bundlebranch measured in 3 cases, and of QRS duration.

\section{Discussion}

Intravenous $0 \cdot 1 \mathrm{mg} / \mathrm{kg}$ metoprolol in human subjects with estimated normal impulse formation and conduction produced significant changes in sinus cycle length and AV nodal conduction and refractoriness.

Mean sinus cycle length was prolonged by 10 per cent, a figure which has also been observed after intravenous $0.08 \mathrm{mg} / \mathrm{kg}$ pindolol (Di Biase et al., 1977a) and $0.1 \mathrm{mg} / \mathrm{kg}$ oxprenolol (Di Biase et al., $1977 \mathrm{~b}$ ), whereas intravenous $0.1 \mathrm{mg} / \mathrm{kg}$ propranolol was found to produce a 16 per cent increase (Stern and Eisenberg, 1969). However, as was noted with 


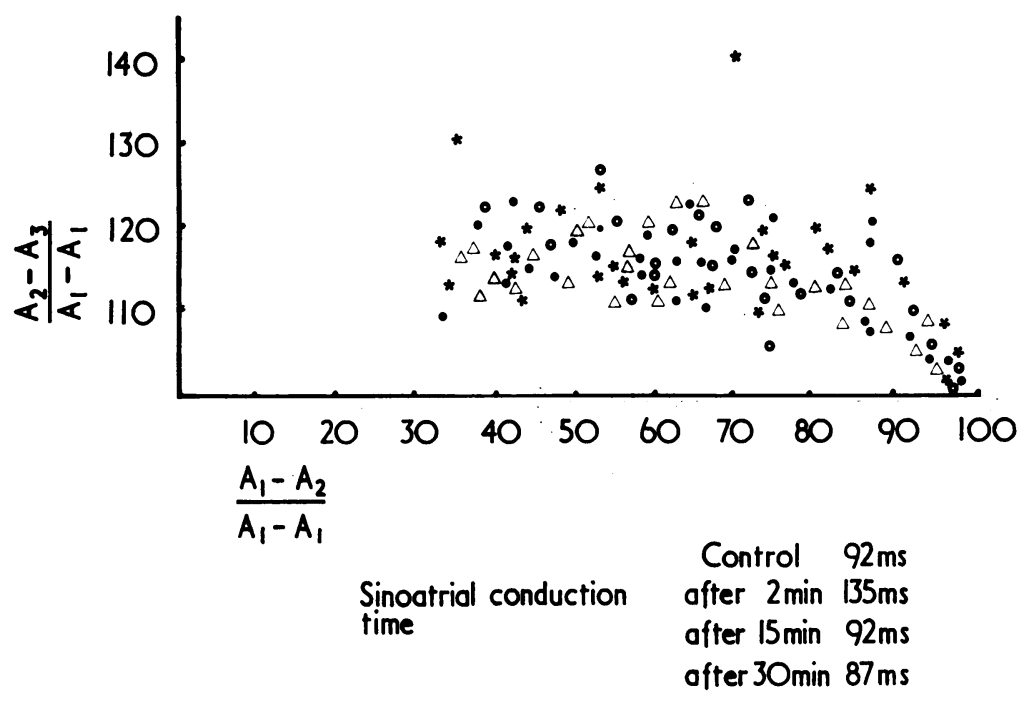

Fig. 1 Effects of atrial premature stimulation on spontaneous sinus rhythm under control conditions and after metoprolol administration. The estimated sinoatrial conduction time is slightly increased.

Control
after $2 \mathrm{~min}$
after $15 \mathrm{~min}$
after $30 \mathrm{~min}$
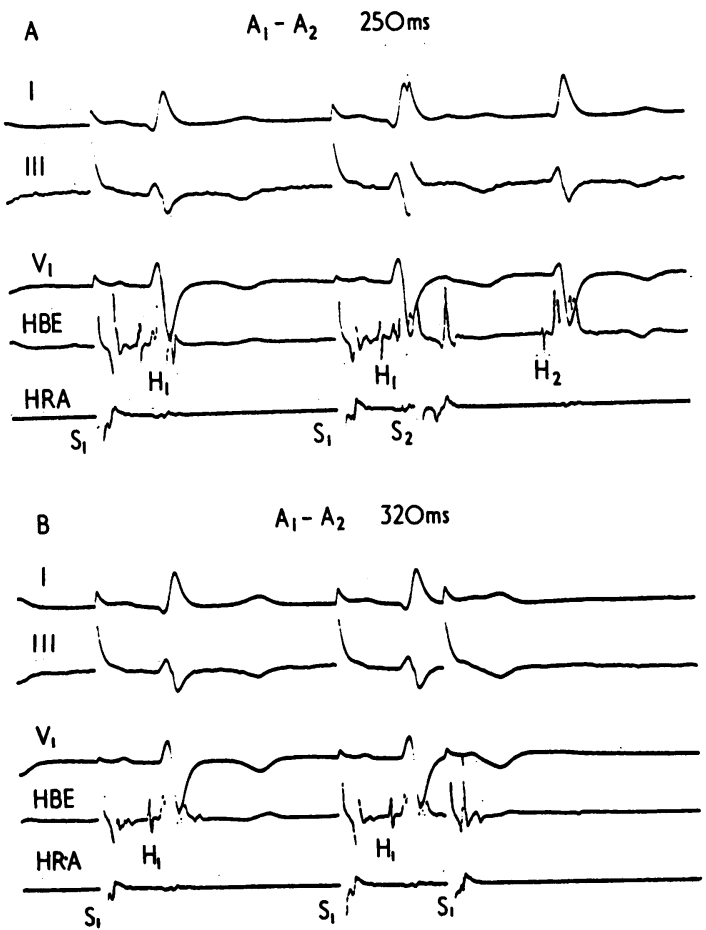

Fig. 2 Effects of metoprolol on effective refractory period of the AV node. Leads I, III, and $V_{1}, H i s$ bundle electrogram (HBE) and right atrial electrogram (HRA). In this subject at paced cycle length of $700 \mathrm{~ms}$ an atrial premature depolarisation $A_{2}$, delivered at a coupling interval of $250 \mathrm{~ms}$, is still conducted to the His bundle (Panel $A$ ). Fifteen minutes after metoprolol, $A_{2}$ delivered at an $A_{1}-A_{2}$ coupling interval of $320 \mathrm{~ms}$ is blocked within the $A V$ node (Panel $B$ ). The effective refractory period of the $A V$ node is increased by $80 \mathrm{~ms}$. 

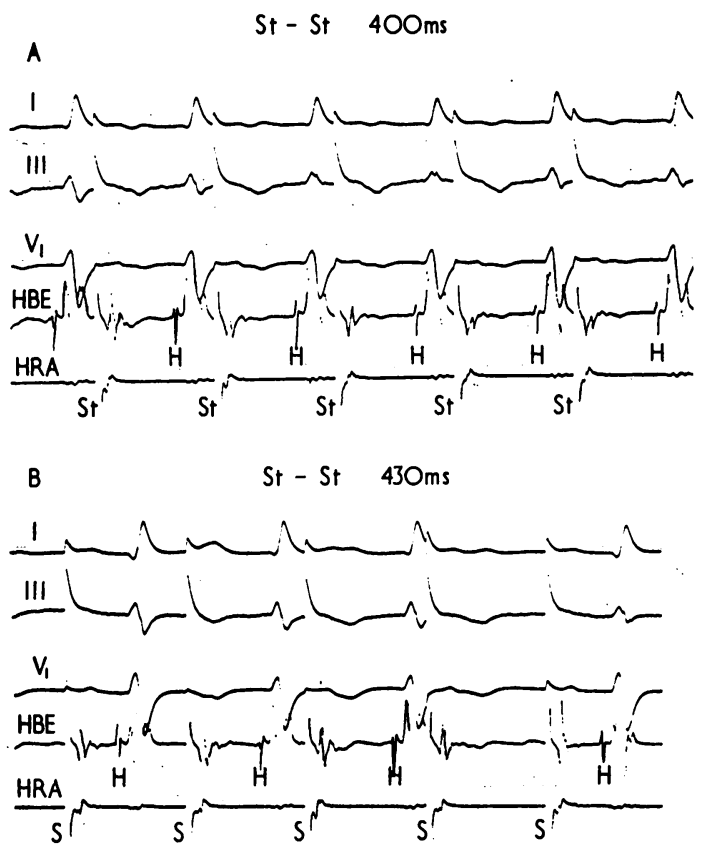

Fig. 3 Effects of metoprolol on the Wenckebach point. In Panel A (control) I:I AV conduction is still present at an atrial paced cycle length of $400 \mathrm{~ms}$ (150 beats min). Fifteen minutes after metoprolol (Panel B), the Wenckebach point is reached at an atrial paced cycle length of $430 \mathrm{~ms}$ (140 beats/min).

pindolol by Di Biase et al. (1977a) and with oxprenolol by Di Biase et al. (1977b), no depression of sinus node intrinsic automaticity seems to occur as suggested by the unchanged sinus node recovery time. Sinoatrial conduction time was slightly prolonged $(P<0.05$ only in the determination at 2 and $15 \mathrm{~min}$ ), a change also found with oxprenolol(Di Biase et al., 1977b) and pindolol (Di Biase et al., 1977a).

Intra-atrial conduction was not modified. Atrial refractoriness was not increased. This lack of effect was found to characterise oxprenolol (Di Biase et al., 1977b), whereas propranolol produced a mild increase (Seides et al., 1974) and pindolol a distinct increase (Di Biase et al., 1977a) in atrial refractoriness.

Intranodal conduction is much depressed as proved by the significant $(P<0.01)$ increase of the $\mathrm{AH}$ interval and the lowering of the Wenckebach point. A consistent prolongation of effective and functional $(P<0.01)$ AV node refractory periods adds a further element in favour of the strong activity of this drug on the AV node. This effect seems common to most $\beta$-blocking agents since it is equally present in propranolol (Seides et al., 1974), pindolol (Di Biase et al., 1977a), and oxprenolol (Di Biase et al., 1977b).
The infranodal conduction system is not affected, as shown by unchanged $\mathrm{HV}$ interval and unchanged His-Purkinje and bundle-branch refractory periods. In this respect again, metoprolol behaves similarly to the other $\beta$-blocking agents.

Because of these electrophysiological properties it may be concluded that metoprolol is a useful drug for controlling sinus tachycardia, ventricular rate in atrial flutter and fibrillation, and for the treatment and prophylaxis of AV nodal re-entrant supraventricular tachycardias. Some caution is to be recommended should it be used in heavy dosages and/or for long periods in subjects with clinical and/or electrocardiographic suspicion of sinus node dysfunction, whereas it should be avoided in subjects with chronic or paroxysmal AV node conduction defects.

On the other hand, the lack of adverse effects on the His-Purkinje system allows the use of this drug also in subjects with intraventricular conduction disturbances.

\section{References}

Ablad, B., Borg, K. O., Carlsson, E., Ek, L., Johnsson, G., Malmfors, T., and Regardh, C. (1975). A survey of the pharmacological properties of metoprolol in animals and man. Acta Pharmacologica et Toxicologica, 36, Suppl. V, 7-23.

Ablad, B., Carlsson, E., and Ek, L. (1973). Pharmacological studies of two new cardioselective adrenergic beta-receptor antagonists. Life Sciences, 12, 107-119.

Di Biase, M., Brindicci, G., and Rizzon, P. (1977a). Effects of pindolol on impulse formation and conduction in man. fournal of Electrocardiology, 10, 45-50.

Di Biase, M., Guglielmi, R., Scarcia, A., Chiddo, A., and Rizzon, P. (1977b). Electrophysiologic properties of intravenous oxprenolol in man. Fournal of Electrocardiology, 10, 267-273.

Johnsson, G. (1975). Influence of metoprolol and propranolol on hemodynamic effects induced by adrenaline and physical work. Acta Pharmacologica et Toxicologica, 36, Suppl. V, 59-68.

Mandel, W., Hayakawa, H., Danzig, R., and Marcus, H. S. (1971). Evaluation of sino-atrial node function in man by over-drive suppression. Circulation, 44, 59-66.

Scherlag, B. J., Lau, S. H., Helfant, R. H., Berkowitz, W. D., Stein, E., and Damato, A. N. (1969). Catheter technique for recording His bundle activity in man. Circulation, 39, 13-18.

Seides, S. F., Josephson, M. E., Batsford, W. P., Weisfogel, G. M., Lau, S. H., and Damato, A. N. (1974). The electrophysiology of propranolol in man. American Heart fournal, 88, 733-741.

Stern, S., and Eisenberg, S. (1969). The effect of propranolol (Inderal) on the electrocardiogram of normal subjects. American Heart fournal, 77, 192-195.

Strauss, H. C., Saroff, A. L., Bigger, J. T., Jr., and Giardina, E. G. V. (1973). Premature atrial stimulation as a key to the understanding of sinoatrial conduction in man. Circulation, 47, 86-93.

Requests for reprints to Professor Paolo Rizzon, Clinica Medica I, Policlinico, 70124 Bari, Italy. 